\title{
Estimation of Compressive Strength of Waste Andesite Powder-Added Concrete Using an Artifical Neural Network
}

\author{
Hakan CEYLAN*, Metin DAVRAZ, Mustafa SIVRI
}

\begin{abstract}
In this study, the effects of using andesite powder wastes-produced from natural stone factories as mineral additives in concrete manufacturing-on the compressive strength of concrete were modeled using an Artificial Neural Network (ANN). To achieve this, cement mixtures were produced by using waste andesite powder (WAP) mixture at ratios of $0 \%$ (control), $10 \%, 15 \%$ and $20 \%$. The effects of curing time were investigated by preparing specimens at 28 and 90 days. The training set was formed by using cement and the specified WAP mixtures and curing time parameters. It was observed that the results obtained from the training ANNs were consistent with the experimental data.
\end{abstract}

Keywords: artificial neural network; concrete compressive strength; waste andesite powder

\section{INTRODUCTION}

Cement production is a costly and environmentally polluting process. Portland cement generates about $7 \%$ of global $\mathrm{CO}_{2}$ emissions, which is the main pollutant in environmental pollution and global climate change. The total amount of global $\mathrm{CO}_{2}$ emissions in 2013 was 36 billion tons, of which industrial $\mathrm{CO}_{2}$ emissions accounted for about $29 \%$, and the cement industry was one of the major industrial sectors generating $\mathrm{CO}_{2}$ emissions [1].

Because of this, studies have been conducted in recent years to decrease the use of cement in concrete production and materials that can be an alternative to cement were developed. There has not yet been any material developed that can be an alternative to cement in concrete production; however, there are some materials showing pozzolanic characteristics that can be added in small amounts into the mixture to decrease the amount of cement used. These materials are like fly-ash, silica fume, blast furnace slag, stone and marble dusts, diatomite, ground pumice, volcanic tuffs and rice crust ash [2].

Studies have been conducted to investigate the contribution of these pozzolans to concrete compressive strength, by using them with Portland cement in specific proportions, and it has been observed that pozzolanic activity emerges following certain curing times, but decreases in strength can also be possible due to decreases in the amount of cement used $[3,4]$. In recent years, many studies have been conducted on the utilization of various pozzolans in concrete, mortar and cement. These are stone dust [5, 6], marble dust [7-11], limestone powder, basalt powder, granulated blast furnace slag, fly ash [12-14], diatomite, pumice $[15,16]$, rice husk ash [17] and volcanic tuff $[18,19]$. Another material showing pozzolanic characteristic is waste andesite powder. The pozzolanic characteristics of andesite are due to its volcanic origins and to the fact that it contains high amounts of $\mathrm{SiO}_{2}$.

An Artificial Neural Networks (ANN) technique used to evaluate multivariable, nonlinear problems is a data processing system that imitates the biological system of the human brain [20]. ANNs are complicated systems consisting of artificial neurons the elementary units of the human brain made by connecting them to each other using different topologies and network models. An Artificial
Neural Network is a parallel-bound, hierarchical organization of many artificial neurons that interact with each other. The calculations performed in an ANN form a new and different data processing technique that creates an alternative to algorithmic programming.

Instead of presenting a method involving incremental processing, a neural network generates its own rules, making associations and regulating those rules by comparing the results with samples [21]. In addition to various uses of the technique in civil engineering, it is also widely used for modeling concrete experiments. In this study, the use of waste andesite powders obtained from andesite manufacturing factories in concrete production as a pozzolanic additive was investigated and then modeled using an Artificial Neural Networks.

\section{MATERIAL AND METHOD}

In this study, CEM I 42.5 R type Portland cement was used as a binder, while waste andesite powder (WAP)supplied from a natural stone factory in the Isparta Municipality of Turkey was used as a mineral additive in the concrete specimens. The chemical and physical properties of WAP are given Tab. 1. The mixtures used continuously-graded coarse aggregate ( 4 to 8,8 to 11.2 , 11.2 to $22.4 \mathrm{~mm}$ ) having a specific gravity of $2.75 \mathrm{~g} / \mathrm{cm}^{3}$ and a water absorption of $0.23 \%$. Crushed sand was used as a fine aggregate having a specific gravity of $2.75 \mathrm{~g} / \mathrm{cm}^{3}$ and water absorption of $0.52 \%$. Mixtures were prepared in accordance with the TS 802 standard [22].

Table 1 Chemical and physical properties of AWP

\begin{tabular}{|c|c|}
\hline Chemical Component & $\%$ \\
\hline $\mathrm{SiO}_{2}$ & 56.34 \\
\hline $\mathrm{Al}_{2} \mathrm{O}_{3}$ & 18.21 \\
\hline $\mathrm{Fe}_{2} \mathrm{O}_{3}$ & 5.61 \\
\hline $\mathrm{MgO}$ & 1.62 \\
\hline $\mathrm{CaO}$ & 4.45 \\
\hline $\mathrm{Na}_{2} \mathrm{O}$ & 3.85 \\
\hline $\mathrm{K}_{2} \mathrm{O}$ & 2.90 \\
\hline $\mathrm{SO}_{3}$ & 0.19 \\
\hline Loss on Ignition & 3.38 \\
\hline Specific Gravity $/ \mathrm{g} / \mathrm{cm}^{3}$ & 2.66 \\
\hline Fineness / cm $/ \mathrm{g}$ & 5790 \\
\hline
\end{tabular}

The total of major oxides for $W A P$ was $80 \%$, which meets TS EN 450 standards (total major oxides $\geq 70 \%$ ). 
The effectiveness factor of $W A P$ in use as a mineral additive was investigated by the authors in a previous study. According to the findings obtained from this research, and the $W A P$ usage rate, $\mathrm{k}$ value is $0.24,0.25$ and 0.75 respectively [23]

A polycarboxylate-ether type super-plasticizer having a density of $1.15 \mathrm{~g} / \mathrm{cm}^{3}$ and $30 \%$ solid content was used to improve the settlement values of fresh concrete in all mixtures. First, settlement tests were applied to all fresh concrete mixtures to obtain a constant settlement value
(200 $\mathrm{mm} \pm 20 \mathrm{~mm})$. The most appropriate water/cement ratios, based on the settlement test, were $0.55,0.30$ and 0.33 for $\mathrm{C} 20, \mathrm{C} 30$ and $\mathrm{C} 40$ mixtures. Considering these findings, 12 different mortar mixtures were prepared to determine the activity factors of the mineral admixtures. Mixture details of the mortars are shown in Tab. 2. WAP was used as the mineral additive in $10 \%, 15 \%$ and $20 \%$ proportions.

Table 2 Mixture ratios of concretes added andesite powder [23]

\begin{tabular}{|c|c|c|c|c|c|c|c|c|c|}
\hline Mixture & $\begin{array}{c}\mathrm{PC} \\
/ \mathrm{kg} / \mathrm{m}^{3}\end{array}$ & $\begin{array}{l}\text { WAP } \\
/ \mathrm{kg} / \mathrm{m}^{3}\end{array}$ & $\begin{array}{l}\text { Super-plasticizer } \\
\qquad / \mathrm{kg} / \mathrm{m}^{3}\end{array}$ & $\begin{array}{l}\text { Crushed } \\
\text { limestone } \\
(0 \text { to } 4 \mathrm{~mm})\end{array}$ & $\begin{array}{l}\text { Crushed } \\
\text { limestone } \\
\text { (4 to } 8 \mathrm{~mm} \text { ) }\end{array}$ & $\begin{array}{c}\text { Crushed } \\
\text { limestone } \\
(8 \text { to } 11.2 \mathrm{~mm})\end{array}$ & $\begin{array}{l}\text { Crushed limestone } \\
\text { (11.2 to } 22.4 \mathrm{~mm})\end{array}$ & $\begin{array}{c}28 \text { days / } \\
\mathrm{MPa}\end{array}$ & $\begin{array}{c}90 \text { days / } \\
\mathrm{MPa}\end{array}$ \\
\hline Control 1 & 326 & 0 & 3.26 & 693 & 313 & 193 & 711 & 53 & 60.96 \\
\hline C 20/10 & 293 & 33 & 3.26 & 692 & 312 & 192 & 709 & 47.09 & 52.42 \\
\hline C 20/15 & 277 & 49 & 3.26 & 691 & 312 & 192 & 708 & 36.22 & 44.85 \\
\hline C 20/20 & 261 & 65 & 3.26 & 690 & 311 & 192 & 707 & 36.35 & 43.07 \\
\hline Control 2 & 419 & 0 & 6.28 & 662 & 299 & 184 & 679 & 70.9 & 72.92 \\
\hline C 30/10 & 377 & 42 & 6.28 & 660 & 298 & 183 & 676 & 57.08 & 66 \\
\hline C 30/15 & 356 & 63 & 6.28 & 658 & 297 & 183 & 675 & 52.18 & 54.58 \\
\hline C 30/20 & 335 & 84 & 6.28 & 657 & 297 & 183 & 674 & 54.52 & 66.76 \\
\hline Control 3 & 538 & 0 & 10.76 & 621 & 281 & 173 & 636 & 83.2 & 88.44 \\
\hline C 40/10 & 484 & 54 & 10.76 & 618 & 279 & 172 & 633 & 69.09 & 70.54 \\
\hline C 40/15 & 457 & 81 & 10.76 & 616 & 278 & 171 & 632 & 70.62 & 80.76 \\
\hline C 40/20 & 430 & 108 & 10.76 & 615 & 278 & 171 & 630 & 70.23 & 74.77 \\
\hline
\end{tabular}

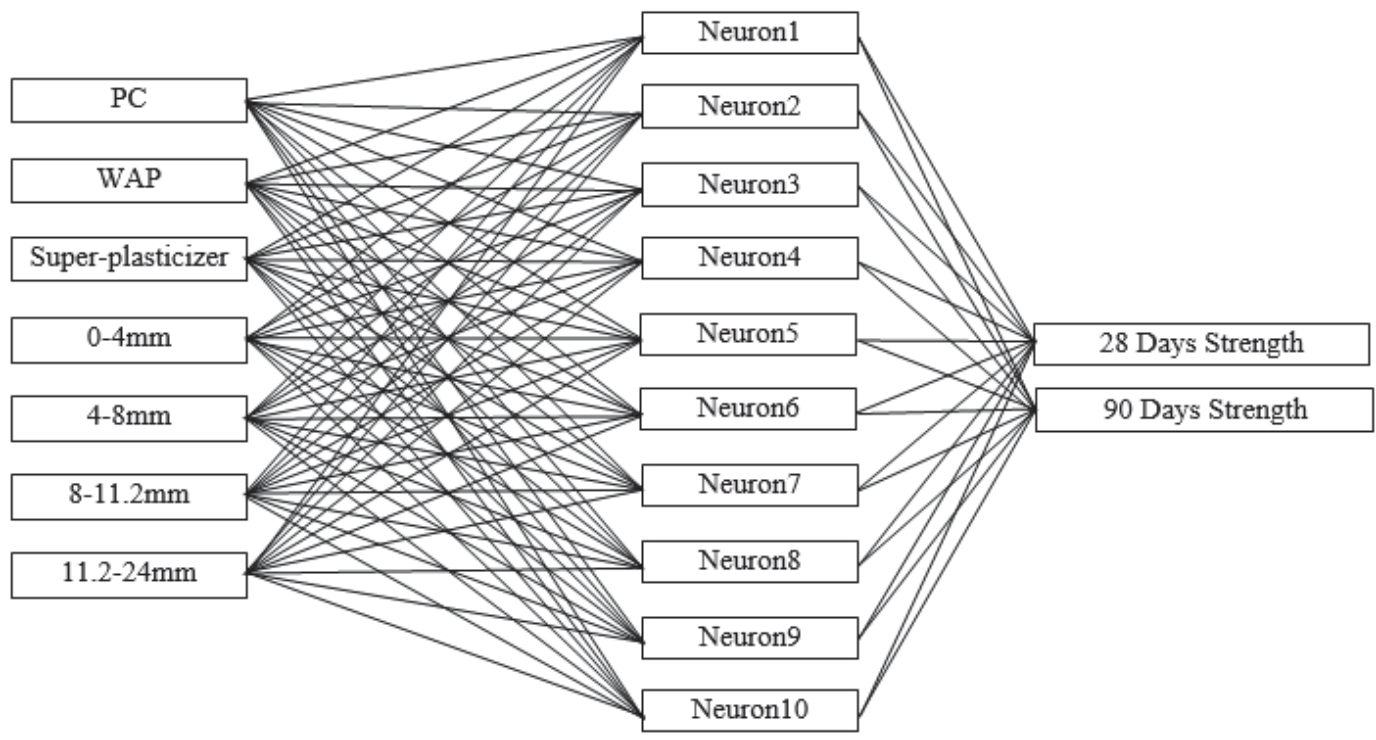

Figure 1 Artificial Neural Network model

Six cubes from each mixture were prepared to conduct compressive strength tests. Samples were covered with a plastic cap. Concrete samples were removed from the mold after 24 hours and immersed into lime-saturated water until test time. Compressive strengths of samples at curing times of 28 and 90 days were determined according to the TS EN 12390-3 standard [24].

An Artificial Neural Network (ANN) model was constructed as follows: cement, WAP, super-plasticizer (SP) and aggregates having 4 different mesh sizes were input; 28 and 90-day compressive strengths of concretes were output (Fig. 1). As indicated in the latent layer consisting of 10 neurons in Fig. 1, the transfer function was defined as a purlin and the result representing the best experimental results was obtained.

\section{RESULT AND DISCUSSION}

The uniaxial compressive strength values of 28 and 90 day concretes added waste andesite powder are shown in Fig. 2 and Fig. 3. The compressive strength values obtained from the control specimens were substantially high. The C30 concrete specimens had strength values of approximately $70 \mathrm{MPa}$ after curing times of 28 and 90 days. It was observed that the compressive strength values of andesite powder-added concretes were lower than the control specimens. However, it should be noticed that compressive strength values increased during a curing time of 90 days. Similar to many other mineral additives, due to the pozzolanic activity of the waste andesite powder, after 28 days of curing period, the compressive strength increased in WAP-added concretes. C30 series having the same amount of WAP admixture, it was observed that the 
compressive strength at 28 days is about $70 \mathrm{MPa}$, while it is approximately $73 \mathrm{MPa}$ at 90 days (from the figures below). Values far above the desired ones were obtained in all the other WAP-added series. Results reveal that the optimum adding amount was $10 \%$; however, admixture amounts above $10 \%$ produced sufficient compressive strength values with increasing curing time and the amount of cement. These data indicate that waste andesite powder can be used as a pozzolan in concrete manufacturing.

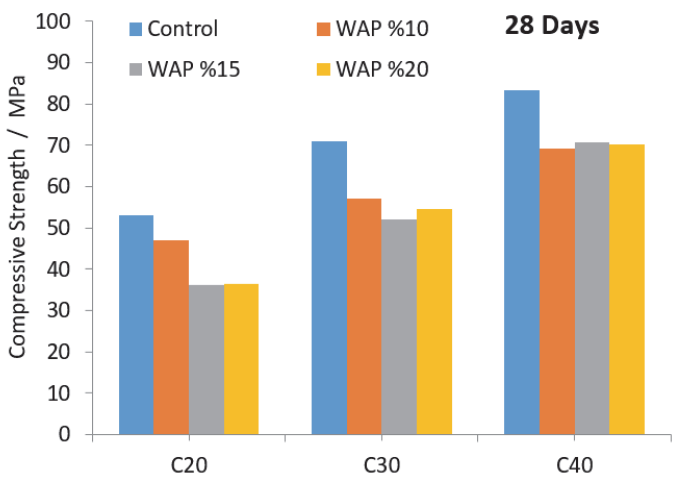

Figure 2 Compressive strengths of concrete specimens at 28 days

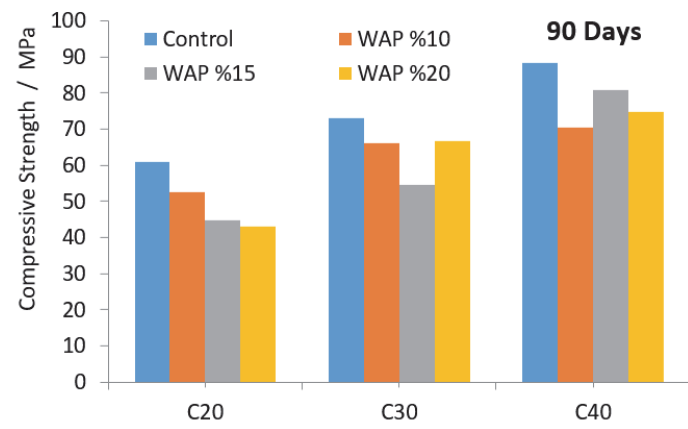

Figure 3 Compressive strengths of concrete specimens at 90 days

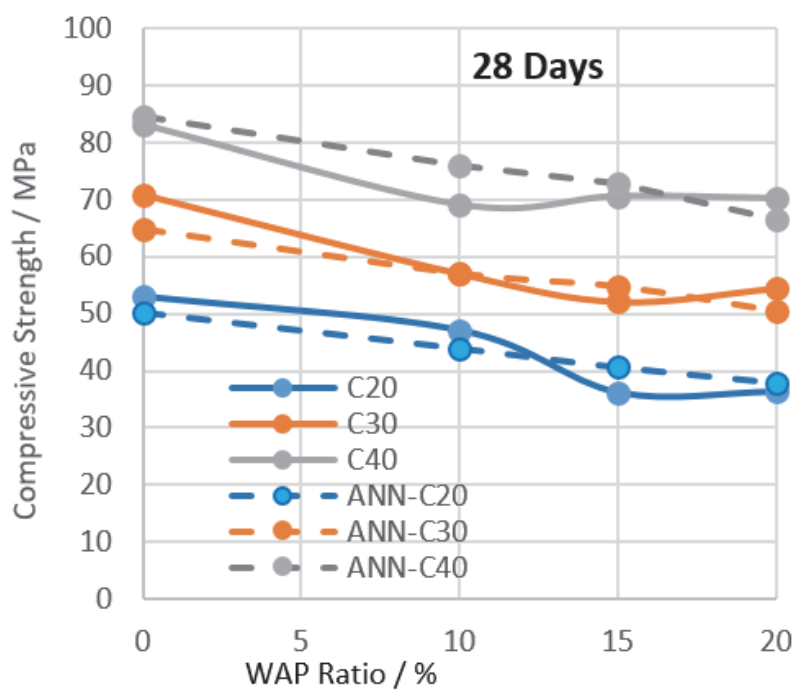

Figure 4 Experimental and ANN modeled values of 28-days compressive strengths of andesite powder-reinforced concretes

The obtained data were compared with the modeled ANN data. The number of ANN input layers was defined as having 7 members by taking all variables used in the mixture. The number of output layers was 2 (28 and 90days compressive strengths). Experimental and ANN modeled values of 28 and 90-day compressive strengths of andesite powder-reinforced concretes are shown in Fig. 4 and Fig. 5.

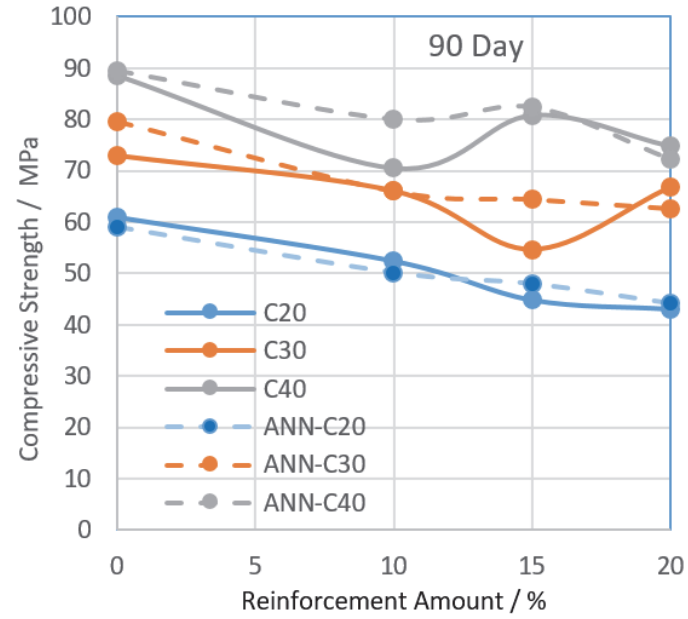

Figure 5 Experimental and ANN modeled values of 90-days compressive strengths of andesite powder-reinforced concretes

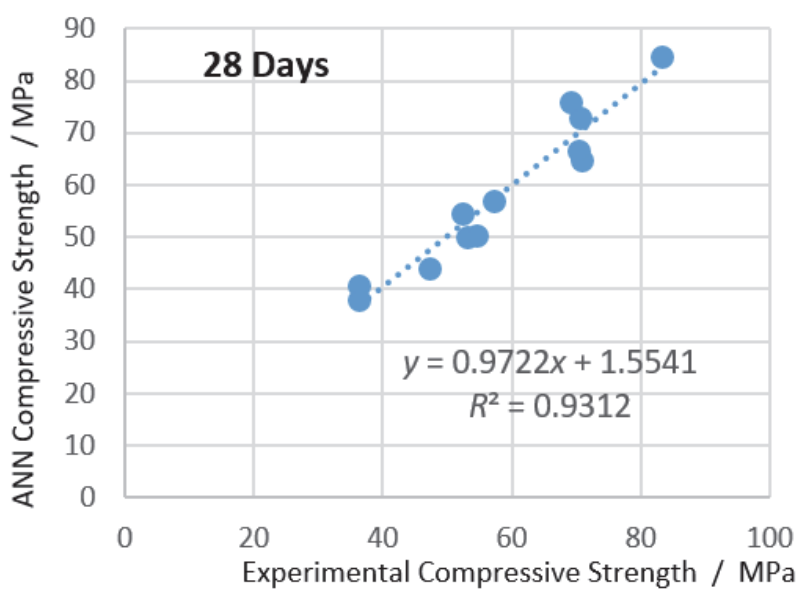

Figure 6 The relationship between experimental results and estimated results using ANN

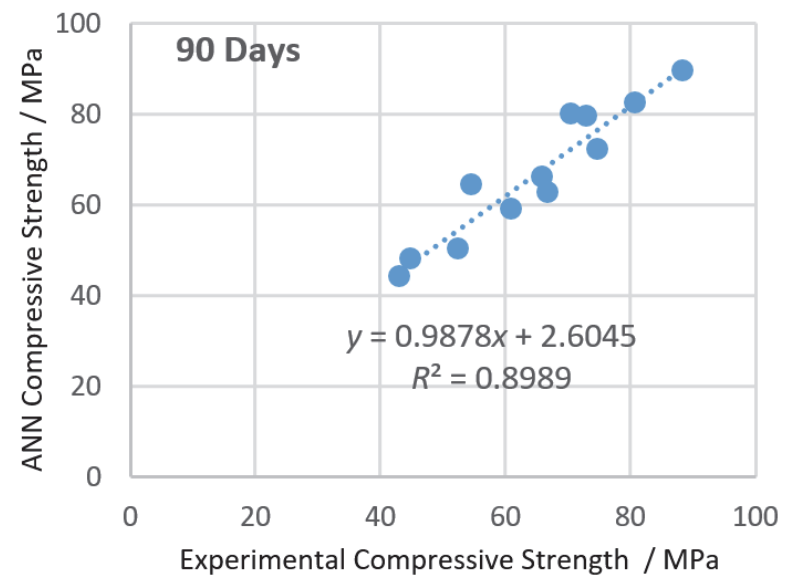

Figure 7 The relationship between experimental results and estimated results using ANN

Experimental and estimated compressive strength values of concrete specimens are shown in Fig. 6 and Fig. 7. It was determined after comparing the ANN model and experimental results that relationship coefficients between 28 and 90 -day compressive strengths were found to be $93 \%$ 
and $90 \%$, respectively. These values are within acceptable limits.

\section{CONCLUSION}

Based on the obtained findings, the use of waste andesite powder in concrete manufacturing as a mineral reinforcement is appropriate due to its pozzolanic characteristics. In this study, an estimation model was developed by using both experimental data and an Artificial Neural Network. Corresponding ratios for the developed model and the experimental results were found to be within $93 \%$ and $90 \%$ of each other for 28 and 90 -day compressive strengths, respectively. When the results of the study are evaluated in terms of the reliability of the model, the correlation relationships between the estimated and experimental values are at acceptable levels.

Investigating the effects of various materials on concrete compressive strength in laboratory conditions is a quite difficult work. Experimental studies require long processes, extensive material use, economic responsibilities and experienced staff. Therefore, reliable and practical results can be obtained by using an ANN model in concrete manufacturing without having to conduct extensive experimental studies using values from different materials.

\section{Acknowledgements}

Authors thank Scientific Research Project Coordination Office of Suleyman Demirel University, Isparta-Turkey for financial support during this research study. (Project Number: SDU-BAP-2603-M-10).

\section{REFERENCES}

[1] Vatopoulos, K. \& Tzimas, E. (2012). Assessment of $\mathrm{CO}_{2}$ capture technologies in cement manufacturing process. $J$ Cleaner Prod, 32, 251-262. https://doi.org/10.1016/j.jclepro.2012.03.013

[2] Ceylan, H. (2016). Effects of volcanic tuff as a partial replacement for cement on the compressive strength of concrete. Oxidation Communication, 39(1-I), 338-347.

[3] Mehta, P. K. (1981). Studies on blended Portland cements containing Santorin earth. Cement and Concrete Research, 4, 507-518. https://doi.org/10.1016/0008-8846(81)90080-6

[4] Khandaker, M. \& Hossain, A. (2004). Properties of volcanic pumice based cement and lightweight concrete. Cement and Concrete Research, 34, 283-291. https://doi.org/10.1016/j.cemconres.2003.08.004

[5] Almedia, N., Branco, F., Santos, J. R. (2007). Recycling of Stone Slurry in Industrial Activities, Application to Concrete Mixtures. Building and Environment, 42, 810-819. https://doi.org/10.1016/j.buildenv.2005.09.018

[6] Almedia, N., Branco, F., Brito, J., \& Santos, J. R. (2007). High-performance Concrete with Recycled Stone Slurry. Cement and Concrete Research, 37, 210-220. https://doi.org/10.1016/j.cemconres.2006.11.003

[7] Topçu, İ. B., Bilir, T., \& Uygunoğlu, T. (2009). Effect of Waste Marble Dust Content as Filler on Properties of Selfcompacting Concrete. Construction and Building Materials, 23, 1947-1953. https://doi.org/10.1016/j.conbuildmat.2008.09.007

[8] Alyamaç, K. E. \& İnce, R.A. (2009). Preliminary Concrete Mix Design for SCC with Marble Powders. Construction and Building Materials, 23, 1201-1210. https://doi.org/10.1016/j.conbuildmat.2008.08.012

[9] Corinaldesi, V., Moriconi, G., T. R., \& Naik, T. R. (2010). Characterization of Marble Powder for Its Use in Mortar and Concrete. Construction and Building Materials, 24, 113117. https://doi.org/10.1016/j.conbuildmat.2009.08.013

[10] Aruntaş, H. Y., Gürü, M. Dayı, M., \& Tekin, İ. (2010). Utilization of Marble Waste Dust as an Additive in Cement Production. Materials and Design, 31, 4039-4042. https://doi.org/10.1016/j.matdes.2010.03.036

[11] Belaidi, A. S. E., Azzouz, L., \& Kenai, S. (2012). Effect of Natural Pozzolana and Marble Powder on the Properties of Self-compacting Concrete. Construction and Building Materials, 31, 251-257. https://doi.org/10.1016/j.conbuildmat.2011.12.109

[12] Uysal, M. \& Y1lmaz, K. (2011). Effect of Mineral Admixtures on Properties of Self-compacting Concrete. Cement and Concrete Composites, 33, 771-776. https://doi.org/10.1016/j.cemconcomp.2011.04.005

[13] Uysal, M. \& Sümer, M. (2011). Performance of Selfcompacting Concrete Containing Different Mineral Admixtures. Construction and Building Materials, 25, 41124120. https://doi.org/10.1016/j.conbuildmat.2011.04.032

[14] Gesoğlu, M., Güneyisi, E., Kocabağ, M. E., Bayram, V., \& Mermerdaş K. (2012). Fresh and Hardened Characteristics of Self-compacting Concretes Made with Combined Use of Marble Powder, Limestone Filler, and Fly ash. Construction and Building Materials, 37, 160-170. https://doi.org/10.1016/j.conbuildmat.2012.07.092

[15] Ergün, A. (2012). Effect of the Usage of Diatomite and Waste Marble Powder as Partial Replacement of Cement on the Mechanical Properties of Concrete. Construction and Building Materials, 25, 806-812. https://doi.org/10.1016/j.conbuildmat.2010.07.002

[16] Aydın, A. C. \& Gül, R. (2007). Influence of Volcanic Originated Natural Materials as Additives on the Setting Time and Some Mechanical Properties of Concrete. Construction and Building Materials, 21, 1277-1281. https://doi.org/10.1016/j.conbuildmat.2006.02.011

[17] Jain, N. (2012). Effect of Nonpozzolanic and Pozzolonic Mineral Admixtures on the Hydration Behaviour of Ordinary Portland Cement. Construction and Building Materials, 27, 39-44. https://doi.org/10.1016/j.conbuildmat.2011.08.006

[18] Balog, A. A., Cobirzan, N., Aciu, C., \& Varvara, D. A. I. (2014). Valorification of Volcanic Tuff in Constructions and Materials Manufacturing Industry. Procedia Technology, 12, 323-328. https://doi.org/10.1016/j.protcy.2013.12.493

[19] Pekmezci, B. Y. \& Akyüz, S. (2004).Optimum Usage of Natural Pozzolan for the Maximum Compressive Strength of Concrete. Cement and Concrete Research, 34, 2175-2179. https://doi.org/10.1016/j.cemconres.2004.02.008

[20] Ji, T., Lin, T., \& Lin, X. (2006). A concrete mix proportion design algorithm based on artificial neural networks. Cement and Concrete Research, 36, 1399-1408. https://doi.org/10.1016/j.cemconres.2006.01.009

[21] Topçu, İ. B., Uygunoğlu, T., \& Sivri, M. (2006). Investigation of effects of Pozzolanas on concrete compressive strength by artificial neural networks. Construction Technologies Electronic Journal, 2, 1-10.

[22] TS 802 (2009). Design of Concrete Mixes. Turkish Standards Institute, Ankara, Turkey.

[23] Ceylan, H. \& Davraz, M. (2017). Utilization of andesite powder waste as mineral admixture in concrete. Journal of Environmental Protection and Ecology, 18(3), 962-977.

[24] TS EN 12390-3 (2010). Testing Hardened Concrete- Part 3: Compressive Strength of Test Specimens. Turkish Standards Institute, Ankara, Turkey. 


\section{Contact information:}

\section{Hakan CEYLAN}

(Corresponding author)

Isparta University of Applied Sciences,

Technical Sciences Vocational School,

Construction Department,

32260 Çünür/lsparta,Turkey

E-mail: ceylanhak@gmail.com

\section{Metin DAVRAZ}

Isparta University of Applied Sciences,

Senirkent Vocational School,

Construction Department,

32260 Çünür/lsparta,Turkey

E-mail: davrazm@gmail.com

\section{Mustafa SIVRI}

Isparta University of Applied Sciences,

Technical Sciences Vocational School,

Construction Department,

32260 Çünür/lsparta,Turkey

E-mail: mustafasivri@isparta.edu.tr 